STUDIA I PRACE WYDZIAŁU NAUK EKONOMICZNYCH I ZARZĄDZANIA nr 41, t. 2

\author{
Eleonora Gonda-Soroczyńska* \\ Hanna Kubicka** \\ Uniwersytet Przyrodniczy we Wrocławiu
}

\title{
WYZWANIA I ZAGROŻENIA ROZWOJOWE OŚRODKÓW UZDROWISKOWYCH NA PRZYKŁADZIE DOLNEGO ŚLĄKA
}

\begin{abstract}
Streszczenie
W opracowaniu zwrócono uwagę na wyzwania i zagrożenia rozwojowe stojące przed ośrodkami uzdrowiskowymi na przykładzie Dolnego Śląska. W Polsce istnieją 43 statutowe uzdrowiska. Aż jedenaście jest położonych w województwie dolnośląskim. Do badań wybrano trzy uzdrowiska: Kudowę-Zdrój, Polanicę-Zdrój i Duszniki-Zdrój. Wybór tych miejscowości nie był przypadkowy, wcześniej badano bowiem wszystkie uzdrowiska dolnośląskie w kontekście uwarunkowań środowiskowych i na podstawie analizy funkcji uzdrowiskowej uznano właśnie te wybrane ośrodki jako najprężniej działające. Wyzwania rozwojowe to konkurencyjność, innowacyjność, zrównoważony rozwój, wielofunkcyjność. Wśród zagrożeń rozwojowych ogólnie pojmowanych na szczególną uwagę zasługują bezrobocie, zmniejszająca się liczba kuracjuszy wynikająca z barier administracyjnych, nieodpowiedni rodzaj i standard oferowanych usług, niewystarczająca infrastruktura uzdrowiskowa, oferta usług leczniczych i towarzyszących, brak szerokiego wachlarza usług turystycznych. Zagrożeniami dla miejscowości uzdrowiskowych są także zanieczyszczenie powietrza i hałas spowodowany intensywnym rozwojem motoryzacji.
\end{abstract}

Słowa kluczowe: uzdrowisko, wyzwania rozwojowe, zagrożenia rozwojowe, konkurencyjność, wielofunkcyjność, atrakcyjność

\footnotetext{
* E-mail: eleonora.gonda-soroczynska@up.wroc.pl

** E-mail: hanna.kubicka@up.wroc.pl
} 


\section{Wprowadzenie}

W opracowaniu zwrócono uwagę na wyzwania i zagrożenia rozwojowe stojące przed ośrodkami uzdrowiskowymi na przykładzie Dolnego Śląska. W Polsce istnieją 43 statutowe uzdrowiska. Aż jedenaście jest położonych w województwie dolnośląskim. Są to: Cieplice Śląskie-Zdrój, Czerniawa-Zdrój, Długopole-Zdrój, Duszniki-Zdrój, Jedlina-Zdrój, Kudowa-Zdrój, Lądek-Zdrój, Polanica-Zdrój, Przerzeczyn-Zdrój, Szczawno- Zdrój, Świeradów-Zdrój. Do badań wybrano trzy uzdrowiska - małe miasta ${ }^{1}$, tj. Kudowę-Zdrój, Polanicę-Zdrój i Duszniki-Zdrój. Wybór tych miejscowości nie był przypadkowy, wcześniej badano bowiem wszystkie uzdrowiska dolnośląskie w kontekście uwarunkowań środowiskowych i na podstawie analizy funkcji uzdrowiskowej uznano właśnie te ośrodki jako najprężniej działające. Opracowane charakterystyki poszczególnych uzdrowisk, w których uwzględniono przede wszystkim takie zagadnienia, jak lokalizacja, usytuowanie; charakterystyka uzdrowiska (w kontekście występowania mineralnych wód leczniczych, borowin, klimatu leczniczego ${ }^{2}$ ); strefy ochronne w uzdrowisku; tereny zielone, w tym: parki zdrojowe, lasy, obszary NATURA 2000 (w samej miejscowości i okolicy); kubaturowa infrastruktura uzdrowiskowa i elementy małej architektury; ład i chaos przestrzenny występujący w miejscowości uzdrowiskowej; powiązania przestrzenne miejscowości uzdrowiskowej z ośrodkiem osadnictwa stałego (określenie rodzaju) ${ }^{3}$. Zwrócono także uwagę na identyfikację systemu przyrodniczego w uzdrowisku poprzez zapoznanie się z różnymi dokumentami planistycznymi takimi jak Projekt Strategii Rozwoju Turystyki w latach 2008-2014; Strategia Rozwoju Województwa Dolnośląskiego do 2020 roku; Program Rozwoju Turystyki Województwa Dolnośląskiego; Studium uwarunkowań i kierunków zagospodarowania przestrzennego analizowanej gminy uzdrowiskowej; plany miejscowe analizowanego uzdrowiska. Wskazano także obszary zagrożeń środowiska przyrodniczego w poszczególnych miejscowościach. W aktualnej rzeczywistości niezwykle ważną cechą jest także atrakcyjność uzdrowisk. Zagrożeniami dla miejscowości uzdrowisko-

Należy zwrócić także uwagę na zagadnienia dotyczące małych miast w okresie transformacji (problemy, wyzwania, perspektywy rozwoju), za: E. Zuzańską-Żyśko, Małe miasta w okresie transformacji. Studium w regionie ślaskim, Wydawnictwo Śląsk, Katowice 2006, s. 207.

2 M. Kluge, T. Kozłowska-Szczęsna, Warunki bioklimatyczne jako podstawa oceny środowiska miejscowości uzdrowiskowo-wypoczynkowej w Sudetach, w: Wykorzystanie i ochrona środowiska ziem poludniowo-zachodnich Polski, red. A. Jahn, PAN Oddział we Wrocławiu, Komitet Nauk o Ziemi, Wrocław 1974, s. $274-290$.

3 A. Jagusiewicz, Problemy funkcjonowania lecznictwa i turystyki w uzdrowiskach, „Rynek Turystyczny” 1999, nr 13-14, s. 19-21; A. Jagusiewicz, Turystyka i lecznictwo w uzdrowiskach polskich, „Problemy Turystyki" 1999 , nr 1, s. 61-76. 
wych są przede wszystkim zanieczyszczenie powietrza, hałas spowodowany intensywnym rozwojem motoryzacji, w niektórych przypadkach rozwijający się przemysł np. górniczy (powodujący zanik leczniczych wód mineralnych), szkody górnicze (stanowiące utrudnienia w funkcjonowaniu uzdrowiska). Zwrócono także uwagę na rewitalizację polskich uzdrowisk trwającą już od wielu lat (zwłaszcza po wejściu Polski do Unii Europejskiej), wykorzystującą sprawdzone wcześniej modele funkcjonujące $\mathrm{w}$ innych krajach, przede wszystkim wysoko rozwiniętych ${ }^{4}$.

Uzdrowiska polskie dysponują bogatymi walorami naturalnymi z właściwościami leczniczymi, źródłami wód mineralnych oraz mikroklimatem ${ }^{5}$. Omawiane miejscowości charakteryzują się nie tylko walorami leczniczymi, lecz także doskonałymi warunkami do uprawiania i rozwoju turystyki, aktywnego wypoczynku, rekreacji, czego dowodem jest poniżej zebrany materiał.

\section{Cel badań, metody badań, hipoteza badawcza}

Głównym celem badań było uzyskanie odpowiedzi na pytania: Jakie wyzwania stoją przed uzdrowiskami w obecnej rzeczywistości? Czy można wskazać zagrożenia dla ich rozwoju? Jeżeli tak, to jakie?

Badania przeprowadzono na podstawie inwentaryzacji bezpośredniej i pośredniej, które należą do metod obserwacji. Bezpośrednia polegała na pracach w terenie, podczas których wykonano inwentaryzacje urbanistyczne, architektoniczne oraz sporządzono dokumentację fotograficzną i wykonano liczne szkice. Zwrócono uwagę na istniejący układ funkcjonalny, układ komunikacyjny, walory środowiskowe, lokalizację poszczególnych obiektów stanowiących infrastrukturę uzdrowiskową, na potencjał uzdrowiskowy, na możliwości adaptacyjne niektórych obiektów, zwłaszcza pod kątem wykorzystania ich ponownie w funkcji uzdrowiskowej, a także na elementy związane z szeroko pojmowaną turystyką i rekreacją, które mogłyby stanowić docelowo istotny produkt turystyczny w rozwoju miejscowości.

Inwentaryzacja pośrednia obejmowała zebranie informacji o historii badanej miejscowości, a zwłaszcza historii uzdrowiska i funkcjonowania poszczególnych obiektów leczniczych. W tej części badań oparto się na materiałach uzyskanych w gminie, wywiadach środowiskowych oraz informacjach zawartych w wyka-

T. Wołowiec, Sposoby rewitalizacji polskich uzdrowisk - ustawa o gminach uzdrowiskowych i inne formy aktywizacji społeczno-gospodarczej, „Folia Turistica” 2003, nr 14, s. 5-29.

5 Zob. także G. Średziński, Krajobraz kulturowy uzdrowisk sudeckich, w: Krajobraz kulturowy uzdrowisk sudeckich, Warszawa 2002. 
zanym piśmiennictwie. Przeprowadzono analizy porównawcze dotyczące ładu przestrzennego, zrównoważonego rozwoju, konkurencyjności, struktury funkcjonalnej, posługując się eksploracją dokumentów planistycznych, literatury fachowej, innych materiałów źródłowych dotyczących określonej jednostki osadniczej. W ocenie struktur funkcjonalno-przestrzennych, powiązań przestrzennych uzdrowiska z ośrodkiem osadnictwa stałego wykorzystano metodę ekspercką. Zgromadzone informacje zostały potwierdzone dokumentacją fotograficzną.

Postawiona hipoteza badawcza brzmi: Każdy ośrodek uzdrowiskowy obszarem wyzwań i zagrożeń rozwojowych.

\section{Współczesny i przyszły model uzdrowisk}

Współczesne uzdrowiska pełnią dwie podstawowe funkcje: leczniczo-rehabilitacyjną oraz czysto turystyczną. Model uzdrowisk oparty wyłącznie na leczeniu uzdrowiskowym, bez prowadzenia działalności wypoczynkowo-turystycznej nie odpowiada współczesnym potrzebom gospodarki rynkowej, która wraz z wprowadzeniem reform społeczno-politycznych w 1999 roku wymusiła całkiem nowe zachowania i inny sposób funkcjonowania ${ }^{6}$.

Kuracji w uzdrowisku nie da się oddzielić od turystyki, od otoczenia, jakie wiąże się z miejscowością uzdrowiskową. Oprócz procedur leczniczych dla kuracjusza ważna jest zmiana środowiska, otoczenia. Także istotne są możliwości udziału w wycieczkach czy imprezach sportowych, uroczystościach lokalnych. Wszystkie atrakcje dotyczące zapełnienia wolnego czasu pozytywnie wpływają na efekt leczenia.

W czasie każdej kuracji należy dbać o cały organizm pacjenta, o człowieka jako całość. Zostało to udowodnione już przez starożytnych lekarzy, którzy działali w dawnych hospicjach, pełniących funkcje ośrodków przywracania zdrowia i odnowy biologicznej.

Interesujący jest współczesny model nowoczesnych uzdrowisk węgierskich. Podstawową zasadą jest tworzenie w nich tzw. parków balneologicznych stanowiących kombinaty wypoczynkowo-lecznicze o powierzchni od 2 do 60 ha. W układzie przestrzennym jest zawarta część rekreacyjna, rozrywkowa, gastronomiczna i lecznicza. Dzięki bogactwu wód leczniczych i dużej liczbie dobrze zagospodarowanych parków balneologicznych na Węgrzech można łączyć pobyt

\footnotetext{
6 Zob. Z. Krasiński, Kondycja turystyki uzdrowiskowej w Polsce a reformy spoleczne 1999 roku, w: Rozwój ustug turystycznych u progu XXI wieku, Poznań 1999, s. 93-120.
} 
wypoczynkowy z możliwością rehabilitacji i korzystania z urządzeń uzdrowiskowych.

\section{Wielofunkcyjność uzdrowisk w gospodarce rynkowej}

W gospodarce rynkowej szczególną uwagę należy zwrócić na wielofunkcyjność kurortów. Bez niej ośrodki jednofunkcyjne są skazane na upadek. Taki jest wymóg czasów współczesnych i prawidłowe pojmowanie właściwie funkcjonujących podmiotów gospodarczych. Pełniąc funkcje lecznicze, miejscowości uzdrowiskowe powinny być równocześnie ośrodkami wypoczynkowymi, centrami odnowy biologicznej, centrami sportowymi, kąpieliskami, stacjami sportów zimowych ${ }^{7}$. Oprócz leczenia i profilaktyki leczniczej uzdrowiska powinny pójść w kierunku rozwoju turystyki kulturalnej (np. festiwale), kongresowej, sportowej, pielgrzymkowej (zwłaszcza w pobliżu znanych sanktuariów), turystyki gier hazardowych ${ }^{8}$. Niekiedy szeroko pojmowane turystyczne funkcje uzdrowiska stają się decydujące dla gospodarki danej miejscowości z uwagi na masowość zadań odbiegających od lecznictwa zamkniętego. Połączenie funkcji leczniczych z innymi funkcjami turystycznymi jest zjawiskiem prawidłowym, ponieważ uzdrowiska oparte tylko na modelu medyczno-terapeutycznym nie zawsze są w stanie radzić sobie w gospodarce rynkowej.

\section{Wyzwania dla ośrodków uzdrowiskowych}

Dla uzdrowiska najważniejszy jest kuracjusz. Bez niego uzdrowisko skazane jest na niebyt. Liczba kuracjuszy w szpitalach i sanatoriach uzdrowiskowych w trzech badanych ośrodkach według dostępnych danych zmieniała się w latach 1995-2004. W latach 1995-1999 w Kudowie-Zdroju i Polanicy-Zdroju była zdecydowanie wyższa niż w latach 2003-2004, natomiast w Dusznikach-Zdroju

\footnotetext{
Zob. także Turystyka a uzdrowiska, red. A. Gotowt-Jeziorska, J. Wyrzykowski, Polskie Stowarzyszenie Turystyki, Warszawa 2005; A. Grzegorczyk, Dolcze vita w spa: hotele spa we Wloszech, „Hotelarz” 2006, nr 2, s. 28-32; A. Hadzik, Znaczenie turystyki uzdrowiskowej w Polsce. Materiaty konferencji: Rola turystyki w strategii i polityce rozwoju gospodarki regionalnej, WSTiH, Gdańsk 2006; E. Ressel, Polskie uzdrowiska, kurorty, sanatoria, spa, centra odnowy biologicznej, Pascal, Bielsko-Biała 2006; K. Rymarczyk-Wajda, Funkcjonowanie uzdrowisk na polskim i zagranicznym rynku turystyki zdrowotnej, „Jedziemy do Wód” 2005, nr 1-2, s. 111-119.

8 Za: Z. Krasiński, Rynek ustug uzdrowiskowych w Polsce, Wyższa Szkoła Zarządzania i Bankowości w Poznaniu; Holding Edukacyjny Paweł Pietrzyk we Wrocławiu, Poznań-Wrocław 2001; Z. Krasiński, Stacja „Sukces Zdrój”, „Aktualności Turystyczne” 2003, nr 5, s. 20-21; Z. Krasiński, Zrównoważony rozwój uzdrowisk, Zeszyty Naukowe Akademii Ekonomicznej w Poznaniu nr 53, Poznań 2004, s. 45-56.
} 
w 2004 roku tylko nieznacznie się obniżyła. Na ten stan wpłynął ich komercyjny charakter, a zwłaszcza wysokie ceny.

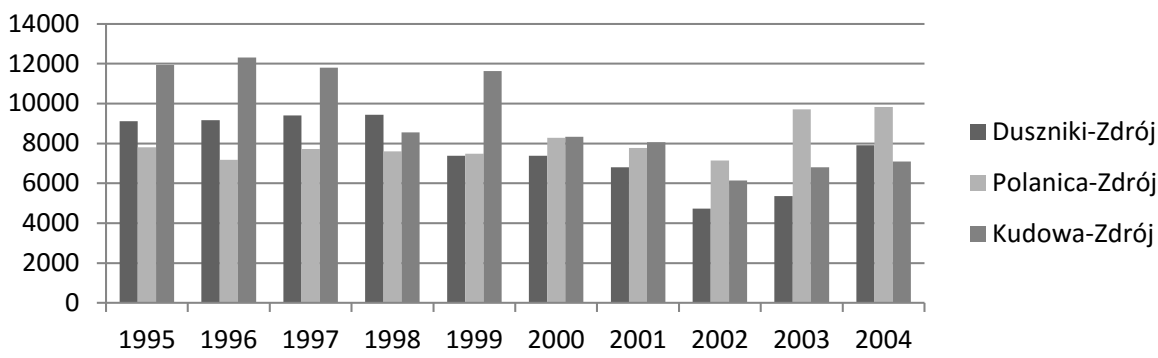

Wykres 1. Liczba kuracjuszy w szpitalach i sanatoriach uzdrowiskowych w Dusznikach-Zdroju, Polanicy-Zdroju i Kudowie-Zdroju w latach 1995-2004

Źródło: opracowanie własne na podstawie danych GUS.

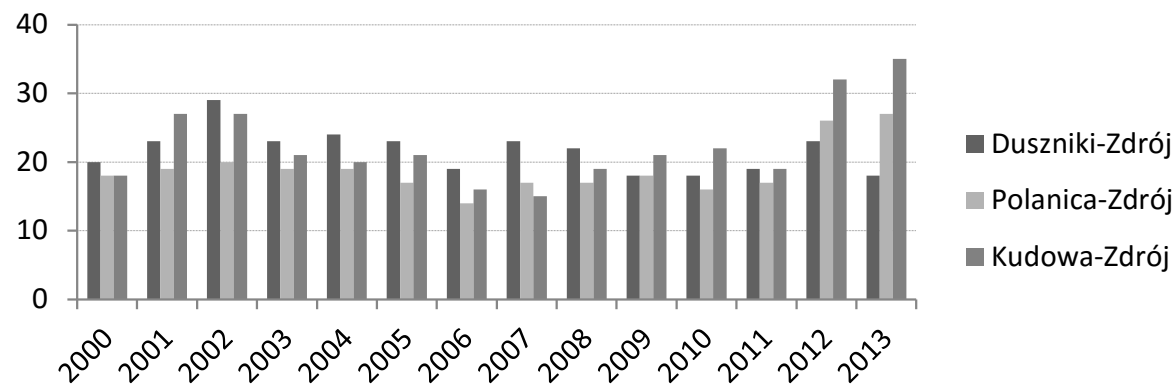

Wykres 2. Liczba turystycznych obiektów noclegowych w Dusznikach-Zdroju, Polanicy-Zdroju i Kudowie-Zdroju w latach 2000-2013

Źródło: opracowanie własne na podstawie danych GUS.

Wprawdzie liczba turystycznych obiektów noclegowych w badanych miejscowościach wzrasta (wykres 2, lata 2012, 2013), jednak wśród wyzwań rozwojowych należy wymienić przede wszystkim takie cechy, jak konkurencyjność, innowacyjność, zrównoważony rozwój, wielofunkcyjność, ograniczanie, a docelowo likwidację bezrobocia.

Prowadzone badania wskazują, że liczba szpitali i sanatoriów uzdrowiskowych maleje na rzecz ośrodków wypoczynkowych. Część z nich została zlikwidowana, część sprywatyzowana (z nastawieniem na usługi komercyjne), a część niszczeje. 


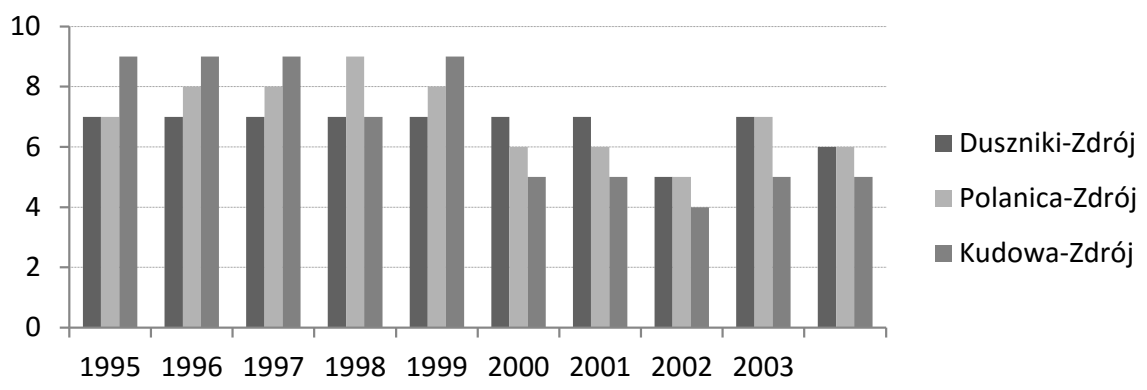

Wykres 3. Liczba szpitali i sanatoriów uzdrowiskowych w Dusznikach-Zdroju, Polanicy-Zdroju i Kudowie-Zdroju w latach 1995-2004

Źródło: opracowanie własne na podstawie danych GUS.

Wyposażenie turystycznych obiektów noclegowych w infrastrukturę towarzyszącą obiektom uzdrowiskowym (np. baseny, boiska, siłownie, zabiegi SPA) sukcesywnie wzrasta, co pokazano na wykresie 4.
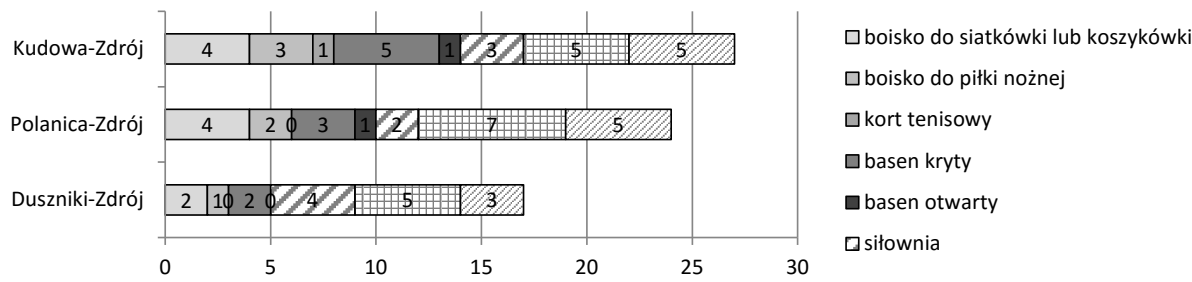

Wykres 4. Wyposażenie turystycznych obiektów noclegowych w Polanicy-Zdroju, KudowieZdroju i Dusznikach-Zdroju w 2013 roku

Źródło: opracowanie własne na podstawie danych GUS.

W sposób szczególny wskazano na rozwój całkiem nowych funkcji oprócz funkcji stricte leczniczej (np. sportowej, rekreacyjnej, kulturowej, spa \& wellness), na rozwój, modernizację, powiększenie bazy noclegowej i gastronomicznej, zwiększenie liczby parkingów, rewitalizację terenów zielonych, zwłaszcza parków zdrojowych.

\section{Zagrożenia rozwoju}

Wśród zagrożeń rozwojowych ogólnie pojmowanych na szczególną uwagę zasługują: zmniejszająca się liczba kuracjuszy wynikająca $z$ barier administracyjnych, nieodpowiedni rodzaj i standard oferowanych usług, nieodpowiednia infrastruk- 
tura uzdrowiskowa, niewystarczająca oferta usług leczniczych i towarzyszących, brak szerokiego wachlarza usług turystycznych (brak wielofunkcyjności). Zagrożeniami są również pyłowe i gazowe zanieczyszczenia powietrza, a także inne ${ }^{9}$. Prowadzone badania wskazują ponadto, że sytuacja analizowanych uzdrowisk jest dużo bardziej korzystna niż tych, w których w miejscu np. funkcji przemysłowej pojawiła się funkcja turystyczna ${ }^{10}$. Pyłowe i gazowe zanieczyszczenia w badanych trzech ośrodkach sukcesywnie maleją, co świadczy o dużym zaangażowaniu w ochronę środowiska. Najkorzystniejszą sytuację mają Duszniki-Zdrój.

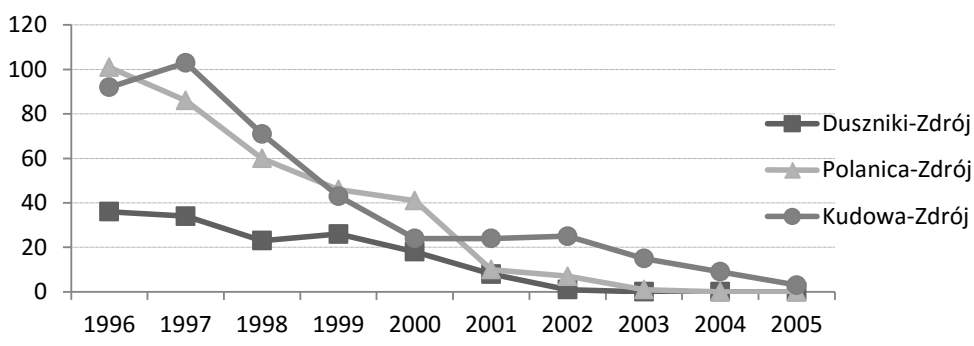

Wykres 5. Pyłowe zanieczyszczenia powietrza w Dusznikach-Zdroju, Polanicy-Zdroju i Kudowie-Zdroju w latach 1996-2005 wyrażone w t/r

Źródło: opracowanie własne na podstawie danych GUS.

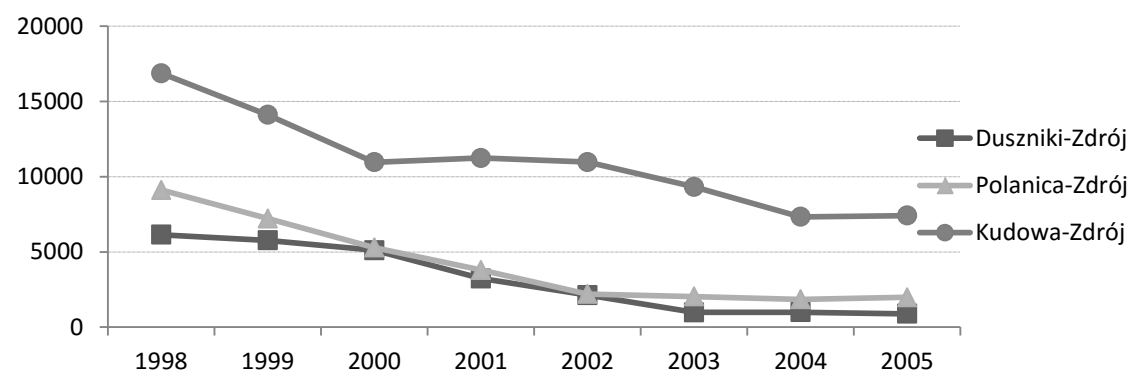

Wykres 6. Gazowe zanieczyszczenia powietrza w Dusznikach-Zdroju, Polanicy-Zdroju i Kudowie-Zdroju w latach 1998-2005 wyrażone w t/r

Źródło: opracowanie własne na podstawie danych GUS.

9 E. Gonda-Soroczyńska, A.M. Soroczyńska, Obszary zagrożeń środowiska przyrodniczego w uzdrowisku na przykładzie Dusznik-Zdroju, Zeszyty Naukowe Uniwersytetu Szczecińskiego. Studia i Prace WNEiZ nr 37, t. 3: Gospodarka regionalna i międzynarodowa, Szczecin 2014.

10 Dobrym przykładem może być Ustroń, za: J. Petryszyn, E. Zuzańską-Żyśko, Od funkcji przemysłowej do turystycznej - przykład Ustronia, w: Funkcja turystyczna miast, XI Konwersatorium Wiedzy o Mieście, red. J. Jażdżewska, Wydawnictwo Uniwersytetu Łódzkiego, Łódź 2008, s. 133-144. 


\section{Podsumowanie}

Cel badań został osiągnięty. Pozwoliły one na wyartykułowanie stwierdzenia, że funkcjonujące na Dolnym Śląsku ośrodki uzdrowiskowe powinny mieć na uwadze wyzwania, jakie stoją przed wszystkimi uzdrowiskami w całej Unii Europejskiej, przede wszystkim wielofunkcyjność. Bez szeroko pojmowanej wielofunkcyjności uzdrowisko może nie przetrwać, gdy weźmie się pod uwagę konkurencyjność nie tylko w kraju, lecz także poza granicami Polski. Funkcjonujące uzdrowiska powinny skierować działania w kierunku współpracy, dbałości o środowisko, tworzenia klastrów turystycznych ${ }^{11}$. Występujące zagrożenia rozwojowe w miarę możliwości należy ograniczać bądź eliminować. Przyszłościowy model uzdrowisk będzie oparty na zasadzie wielofunkcyjnego parku balneologicznego na wzór już funkcjonujących parków węgierskich.

\section{Literatura}

Gonda-Soroczyńska E., Innowacyjny klaster Zdrowie i Turystyka elementem wspótpracy na rzecz rozwoju turystyki uzdrowiskowej w województwie świętokrzyskim, Prace Naukowe Uniwersytetu Ekonomicznego we Wrocławiu nr 157, Wrocław 2011, s. 437-446.

Gonda-Soroczyńska E., Soroczyńska A.M., Obszary zagrożeń środowiska przyrodniczego w uzdrowisku na przykładzie Dusznik-Zdroju, Zeszyty Naukowe Uniwersytetu Szczecińskiego, Studia i Prace WNEiZ nr 37, t. 3: Gospodarka regionalna i międzynarodowa, Szczecin 2014.

Grzegorczyk A., Dolcze vita w spa: hotele spa we Wtoszech, „Hotelarz” 2006, nr 2.

Hadzik A., Znaczenie turystyki uzdrowiskowej w Polsce. Materiaty konferencji: Rola turystyki w strategii i polityce rozwoju gospodarki regionalnej, WSTiH, Gdańsk 2006.

Jagusiewicz A., Problemy funkcjonowania lecznictwa $i$ turystyki $w$ uzdrowiskach, „Rynek Turystyczny” 1999, nr 13-14, s. 19-21.

Jagusiewicz A., Turystyka i lecznictwo w uzdrowiskach polskich, „Problemy Turystyki” 1999, nr 1, s. 61-76.

Kaczyńscy I. i T., Polska. Najpiękniejsze uzdrowiska, Muza, Warszawa 2006.

Kluge M., Kozłowska-Szczęsna T., Warunki bioklimatyczne jako podstawa oceny środowiska miejscowości uzdrowiskowo-wypoczynkowej w Sudetach, w: Wykorzystanie i ochrona środowiska ziem poludniowo-zachodnich Polski, red. A. Jahn, PAN Oddział we Wrocławiu, Komitet Nauk o Ziemi, Wrocław 1974, s. 274-290.

11 E. Gonda-Soroczyńska, Innowacyjny klaster Zdrowie i Turystyka elementem współpracy na rzecz rozwoju turystyki uzdrowiskowej w województwie świętokrzyskim, Prace Naukowe Uniwersytetu Ekonomicznego we Wrocławiu nr 157, Wrocław 2011, s. 437-446. 
Krasiński Z., Kondycja turystyki uzdrowiskowej w Polsce a reformy społeczne 1999 roku, w: Rozwój ustug turystycznych u progu XXI wieku, Poznań 1999, s. 93-120.

Krasiński Z., Rynek usług uzdrowiskowych w Polsce, Wyższa Szkoła Zarządzania i Bankowości w Poznaniu; Holding Edukacyjny Paweł Pietrzyk we Wrocławiu, Poznań-Wrocław 2001.

Krasiński Z., Stacja „,Sukces Zdrój”, „Aktualności Turystyczne” 2003, nr 5, s. 20-21.

Krasiński Z., Zrównoważony rozwój uzdrowisk, Zeszyty Naukowe Akademii Ekonomicznej w Poznaniu nr 53, Poznań 2004, s. 45-56.

Petryszyn J., Zuzańska-Żyśko E., Od funkcji przemysłowej do turystycznej - przykład Ustronia, w: Funkcja turystyczna miast, XI Konwersatorium Wiedzy o Mieście, red. J. Jażdżewska, Wydawnictwo Uniwersytetu Łódzkiego, Łódź 2008, s. 133-144.

Ressel E., Polskie uzdrowiska, kurorty, sanatoria, spa, centra odnowy biologicznej, Pascal, Bielsko-Biała 2006.

Rymarczyk-Wajda K., Funkcjonowanie uzdrowisk na polskim i zagranicznym rynku turystyki zdrowotnej, ,Jedziemy do Wód” 2005, nr 1-2, s. 111-119.

Średziński G., Krajobraz kulturowy uzdrowisk sudeckich, w: Krajobraz kulturowy uzdrowisk sudeckich, Warszawa 2002.

Turystyka a uzdrowiska, red. A. Gotowt-Jeziorska, J. Wyrzykowski, Polskie Stowarzyszenie Turystyki, Warszawa 2005.

Zuzańska-Żyśko E., Małe miasta $w$ okresie transformacji. Studium w regionie ślaskim, Wydawnictwo Śląsk, Katowice 2006.

\title{
DEVELOPMENT CHALLENGES AND THREATS OF SPA RESORTS BASED ON THE EXAMPLE OF LOWER SILESIA REGION
}

\begin{abstract}
The study has been focused on development challenges and threats faced by spa resorts based on the example of Lower Silesia region. Poland has 43 statutory spa resorts. As many as 11 of them are located in Lower Silesia region. The research covered 3 spa resorts, i.e. Kudowa-Zdrój, Polanica-Zdrój and Duszniki-Zdrój. The selection of these locations was not random, since previously all Lower Silesian spa resorts were analyzed in the context of environmental determinants and the above-mentioned locations were considered the most effectively operating centers regarding their spa function and also developing new, other functions in terms of broadly understood tourism. This development challenges: competitiveness, innovativeness, sustainable development and multi-functionality. As far as the generally perceived development threats are concerned particular attention should be paid to: unemployment, decreasing number of visitors seeking treatment resulting from administrative barriers, inadequate type and standard of services provided, insuf-
\end{abstract}


ficient spa resort infrastructure and the offer of therapeutic and associated services or the absence of broad spectrum of tourist services. Spa resorts also face such threats as: air pollution, noise caused by intensive development of automotive industry.

Translated by Hanna Fujak

Keywords: spa resort, development challenges, development threats, competitiveness, multi-functionality, attractiveness

JEL codes: $O, R$ 
